\section{Are Small Rural Banks Vulnerable to Local Economic Downturns?}

\author{
Andrew P. Meyer and Timothy J. Yeager
}

\section{RISKINESS OF GEOGRAPHICALLY CONCENTRATED BANKS}

$\square$ $n$ recent years, supervisory agencies have streamlined the bank examination process to focus attention on identified risk areas rather than the full scope of bank operations (Board of Governors, 1997). If supervisors can identify the potential risks, they can recommend preventive measures and respond more quickly to actual banking problems when they arise. Because of this shift to risk-focused supervision, off-site surveillance of banks has become much more important. Supervisory economists and staff who gather and interpret bank and economic data must direct examiners to areas of heightened risks.

Historical experience in the financial services industry demonstrates that institutions exposed to serious risk can run into trouble quickly. Many commercial banks were exposed to fluctuations in commercial real estate markets in the latter half of the 1980s. A sharp decline in real estate prices caused several hundred banks to fail (FDIC, 1997). In addition, agricultural bank failures represented a large share of the banks that failed from 1984 to 1987. These failures occurred within a few years after the peak in farmland prices, reflecting the inability of agricultural banks to absorb the losses accruing from falling farm incomes (Kliesen and Gilbert, 1996). Because these banks were not diversified in terms of geography or industry, the losses eventually overwhelmed the equity accumulated during the prosperous years. If exposure to these risks had been targeted as potential problems earlier, they might have been addressed sooner and their negative impacts dampened.

Andrew P. Meyer is an economist, and Timothy J. Yeager is an economist and senior manager at the Federal Reserve Bank of St. Louis. We thank Boyd Anderson for his invaluable research assistance and Mark Vaughan, Alton Gilbert, Dusan Stojanovic, Tom King, David Wheelock, Ken Spong, Michele Gambera, Bob Rasche, Rick Sullivan, and Ron Feldman for their comments. Thomas A. Pollmann provided research assistance.
Because of the way that U.S. banking laws evolved, many U.S. banks have geographically concentrated offices and operations. Historically, national and state banking laws prevented banks from branching into other counties and states. Justification for such legislation was to promote sound and stable banking markets by limiting competitive pressures on existing banks and to prevent an excessive concentration of financial power (Spong, 2000, p. 146, and Jayaratne and Strahan, 1997). As we have noted, however, such laws left banks vulnerable to local economic downturns.

Over the last few decades, branching restrictions gradually have been lifted. By 1990, most states had granted banks permission to branch within state boundaries, and most states permitted some form of interstate banking (Berger et al., 1995, pp. 188-89). The Riegle-Neal Interstate Banking and Branching Efficiency Act of 1994 removed most remaining barriers to interstate branching. Bank holding companies (BHCs) were allowed to acquire a bank in any state and-as of June 1, 1997-merge it with an existing bank. ${ }^{1}$ Hence, most of the legal barriers to geographical expansion have been removed.

Despite liberalized branching laws, thousands of small banks with geographically concentrated offices remain and are likely to exist for some time. ${ }^{2}$ Some argue that small banks have a comparative advantage over large banks in smallbusiness lending for which little public information about the borrower's creditworthiness is available. This advantage (and thus incentive to remain small) arises because small banks can originate and monitor relationship loans at a lower cost than larger banks. ${ }^{3}$ Relationship lending requires that loan officers have autonomy to set underwriting standards and discretion to monitor and evaluate borrowers. Management at small banks can more easily monitor loan officers; consequently, small banks are better able to develop the community relationships necessary to underwrite small business loans. In addition, anecdotal evidence

\footnotetext{
Montana and Texas initially opted out of this system, but Texas reversed its decision in 1999.

2 Such banks are more prevalent in non-western states that historically had severe intrastate branching restrictions (Gilbert, 2000).

3 See Berger et al. (1998), Peek and Rosengren (1998), and Keeton (1995) for evidence supporting the small bank advantage hypothesis; see Jayaratne and Wolken (1999) for evidence against the hypothesis.
} 
suggests that branch managers of large banks are rotated more often into and out of communities as they progress in their organizations; therefore, they do not develop the same personal relationships with customers that long-time community bankers develop. To contain loan origination and monitoring costs, larger banks often prefer to lend to customers for which credit information is more readily available. Consequently, community banks are likely to continue engaging in small-business lending where assessments of credit quality rely heavily on intangibles.

Two additional factors may limit community bank consolidation, at least in the short- to medium-term. First, most community banks are unit banks; larger banks seeking to expand often prefer to purchase banks with branching networks. Second, community banks that are family-owned and managed are put on the market infrequently. Hence, even some relatively unprofitable community banks could remain in the banking industry for some time.

Despite the continued presence of geographically concentrated banks, we find little evidence to support the hypothesis that such banks located in the Federal Reserve's Eighth District are particularly vulnerable to local economic downturns. Specifically, we find that county economic data are only weakly correlated with small rural bank performance. Our results provide little justification for bank supervisors to require geographically concentrated banks to take special measures to reduce their vulnerability to local economic downturns. In addition, we find little basis for systematically using county-level economic data in risk-focused supervision.

\section{IS BANK PERFORMANCE CORRELATED WITH LOCAL ECONOMIC DATA?}

In this section, we investigate the empirical relationship between the performance of geographically concentrated banks and local economic activity. Banks with geographically concentrated operations are potentially vulnerable to local economic contractions because of an inherent concentration of loan and deposit customers.

Laderman, Schmidt, and Zimmerman (1991) find that a bank's location significantly influences its choice of borrowers because monitoring costs increase as the distance between lender and borrower increases. Hence, banks tend to make loans to the people and businesses that are geographically nearby. Should many firms in the area become distressed at the same time, the bank's credit quality will likely suffer more than credit quality at a bank with credit dispersed across economic markets. In addition, liquidity risk is likely to be higher at geographically concentrated banks because such banks often rely on deposits from fewer entities. In contrast, a more geographically diversified bank can attract deposits from a larger base of individual and business customers; therefore, large swings in deposits and withdrawals are less likely (Liang and Rhoades, 1988).

If local economic activity affects bank performance, this association is more likely to be evident in the data for small banks with offices in rural areas than for other banks. Smaller banks (as measured by assets) typically have more geographically concentrated operations and, due to their lower levels of capital, lend to smaller, less diversified businesses. Therefore, the performance of small banks may depend more heavily on local conditions. Bank performance also is more likely to be correlated with local economic data in rural rather than urban areas because rural banks tend to lend to a relatively high percentage of firms and residents in their own counties. If enough of those firms or residents are faring poorly, local economic data should reflect the poor performance. In contrast, banks located in metropolitan areas usually lend to a smaller fraction of all the firms and individuals in their area. Poor performance by individual small businesses and households will likely have less effect on measures of aggregate economic activity in urban areas than in rural areas.

\section{METHODS}

\section{Data Collection}

We obtained financial data on small rural banks - those with less than $\$ 300$ million in assets located outside of a Metropolitan Statistical Area (MSA)-between 1990 and 1997 from the Reports of Condition and Income (call reports). We chose the $\$ 300$ million size limit because it is commonly used in the banking industry to define small banks, yet the size cutoff is high enough that most banks in rural areas are included in the sample. ${ }^{4}$ We excluded banks less than five years old

\footnotetext{
4 Indeed, banks with assets less than $\$ 300$ million file a call report that is different from the report filed by larger institutions.
} 
FEDERAL RESERVE BANK OF ST. LOUIS

\section{Table 1}

Summary Statistics: Bank Performance and Economic Variables, 1990-97

\begin{tabular}{llcrrr} 
& Number & Mean & $\begin{array}{c}\text { Standard } \\
\text { deviation }\end{array}$ & Minimum & Maximum \\
\hline Bank performance measures & & & & & \\
Adjusted ROA & 6,741 & 1.75 & 0.65 & -5.12 & 10.67 \\
Nonperforming loans to total loans & 6,741 & 1.23 & 1.63 & 0.00 & 78.35 \\
Loan losses to total loans & 6,741 & 0.33 & 0.70 & -9.65 & 16.71 \\
OREO to total assets & 6,741 & 0.20 & 0.43 & 0.00 & 13.67 \\
& & & & & \\
Economic variables & & & & & \\
County unemployment rate & 6,740 & 7.55 & 2.61 & 2.20 & 22.20 \\
State unemployment rate & 6,741 & 5.98 & 1.00 & 3.50 & 8.76 \\
County employment growth & 5,781 & 1.30 & 3.92 & -15.42 & 33.97 \\
State employment growth & 6,741 & 1.09 & 1.95 & -3.59 & 7.44 \\
County per capita income growth & 6,034 & 2.41 & 3.09 & -12.68 & 21.51 \\
State per capita income growth & 6,035 & 1.84 & 1.30 & -0.74 & 4.86 \\
County personal income growth & 6,034 & 2.90 & 3.04 & -12.73 & 23.65 \\
State personal income growth & 6,035 & 2.64 & 1.43 & -0.11 & 6.28
\end{tabular}

NOTE: The bank sample includes Eighth District banks with less than \$300 million in assets located outside an MSA, and the performance measures are standard ratios used in bank supervision to assess bank performance. County and state economic data are matched by year with the headquarters county and state of each bank in the sample. County economic data have much higher standard deviations than state economic data.

Adjusted ROA, net income plus provision expense as a percentage of total assets; nonperforming loans, loans past due 90 days or more plus nonaccrual loans as a percentage of total loans; loan losses, charge-offs minus recoveries as a percentage of total loans; and OREO, other real estate owned as a percentage of total assets.

because new banks have erratic ratios that could bias the results against finding a correlation of performance with economic data. We did not exclude banks involved in merger activity as long as the post-merger bank size did not exceed $\$ 300$ million. Inclusion of these banks potentially biases the sample against finding correlation if the merger results in a more diverse operating market for the acquiring bank, but we deal explicitly with that issue below. Although banking data are readily available before 1990, county-level labor data were significantly revised in 1990, and a consistent time series before then is not available. Because labor data are lagging indicators of the business cycle, the sample period should pick up the effects of both the 1990-91 recession and the subsequent expansion.

To make our study directly relevant to the Federal Reserve's Eighth District risk-focused process and to limit county-level data collection to a reasonable size, we looked at the Eighth District only, which includes banks in Arkansas, eastern Missouri, southern Illinois, southern Indiana, western Kentucky, western Tennessee, and northern Mississippi.

We obtained four different pairs of county and state economic data from the Bureau of Labor Statistics and the Bureau of Economic Analysis. These data include unemployment rates, employment growth, personal income growth, and per capita personal income growth. The criteria for including a regional economic variable in the data set were that the information had to be published at least annually at both the state and county levels and enough observations had to be available in each county to make meaningful statistical inferences. ${ }^{5}$ Because neither the county economic data nor the bank performance data were seasonally

\footnotetext{
5 County bankruptcy data are available annually, but personal bankruptcies had little to do with economic conditions during the 1990s. Building permits are also available; however, rural counties often lack enough observations to make reliable inferences.
} 
adjusted, we used year-end call report data and average annual economic data to smooth out monthly and quarterly fluctuations. Summary statistics for the sample banks and economic variables are reported in Table 1 .

To measure bank performance, we used three asset quality ratios and one earnings ratio that are commonly used in bank supervision to monitor a bank's condition. Deterioration in asset quality and, hence, earnings are the primary reasons that small banks become distressed. The asset quality ratios chosen were nonperforming loans to total loans, net loan losses to total loans, and other real estate owned (OREO) to total assets. Nonperforming loans are loans 90 days or more past due or nonaccruing, net loan losses are charge-offs less recoveries, and OREO is the value of the temporary real estate assets on the bank's books as a result of debtor default. The earnings ratio chosen was adjusted return on assets (ROA) or net income plus provision expense, divided by assets. We added back provision expense because the asset quality measures already account for credit effects. Other things equal, we expected asset quality and earnings to improve with employment and income growth and to worsen with a rise in the unemployment rate.

\section{Regression Model}

We used ordinary least-squares (OLS) regression and tobit analysis to test whether rural bank performance depends on state and county economic variables. We used OLS for each regression involving adjusted ROA and net loan losses; however, we used a tobit procedure for each regression in which nonperforming loans or OREO was the dependent variable because these two variables are censored at zero. ${ }^{6}$

A simple methodology that regresses bank performance measures on local economic data suffers from omitted variable bias because several factors besides local economic conditions affect bank performance. We included bank-specific intercepts, lagged bank performance ratios, and state economic data as explanatory variables to reduce the bias. The intercept terms control for bank-specific effects on the levels of performance ratios. For example, some banks may have higher ROA than other banks because managers at the more profitable banks are more competent or take more risks than other banks' managers. Lagged bank performance ratios control for persistence in performance. For example, a bank that has high nonperforming loans one year is more likely to have high nonperforming loans the next year because it takes time for borrowers to improve their cash flows and for banks to sever their relationships with customers who are in poor financial condition. ${ }^{7}$ Finally, research has demonstrated a strong link between bank performance and state economic data; therefore, we included state economic data in the initial regression equation to reduce omitted variable bias. ${ }^{8}$

We regressed the four bank performance ratios on lagged performance ratios and the four pairs of county and state economic variables between 1990 and 1997:

(1) $B P_{i t}=\alpha_{i}+\gamma_{0} \cdot B P_{i, t-1}+\gamma_{1} \cdot$ CEcon $_{i t}+\gamma_{2} \cdot$ SEcon $_{i t}+e_{i t}$.

In equation (1), $B P_{i t}$ represents bank $i$ 's performance at time $t$. The $\alpha_{i}$ coefficient is the bankspecific intercept term. The variables $C E c o n_{i t}$ and $S E c o n_{i t}$ represent, respectively, county and state economic data relevant to bank $i$ at time $t$. We matched economic data with the county and state of the bank's headquarters. We tested lagged economic variables, but they contributed insignificant explanatory power to the model. We ran a separate regression for each pair of county and state economic variables to avoid multicollinearity across the different economic variables. For example, the first regression included the county and state unemployment rates of the bank's headquarters, the second regression included only county and state employment growth, and so on.

To properly assess the vulnerability of small rural banks to local economic activity, the primary focus was on the economic and statistical signifi-

\footnotetext{
6 Results from a straight OLS regression for nonperforming loans and OREO were quite similar to the tobit results because the nonnegative constraint was nonbinding for a majority of banks.

7 Nickell (1981) has shown that, in a fixed-effects model, a lagged dependent variable coefficient will be biased unless the number of time periods is large. To a lesser extent, this bias can carry over into the other variables if they are correlated with the lagged dependent variable. This potential bias is not worrisome in our context, however, because our primary concern is with the explanatory power of each county economic variable relative to its state counterpart. In addition, we tested the effect of this bias by dropping the lagged dependent variable from the analysis. The results showing that state economic data influenced bank performance much more than county data remained unchanged.

8 See Neely and Wheelock (1997), FDIC (1997), and Laderman, Schmidt, and Zimmerman (1991).
} 
The "Large Change" Test as a Measure of Economic Significance

\begin{tabular}{lccccc} 
& $\begin{array}{c}\text { 2-Rated } \\
\text { banks }\end{array}$ & $\begin{array}{c}\text { Number } \\
\text { of 2-ratings }\end{array}$ & $\begin{array}{c}\text { 3-Rated } \\
\text { banks }\end{array}$ & $\begin{array}{c}\text { Number of } \\
\text { 3-ratings }\end{array}$ & Difference \\
\hline Bank performance measures & & & & & \\
Adjusted ROA & 1.61 & 636 & 1.12 & 150 & 0.49 \\
Nonperforming loans to total loans & 1.53 & 546 & 2.64 & 129 & 1.11 \\
Loan losses to total loans & 0.42 & 546 & 0.89 & 129 & 0.47 \\
OREO to total assets & 0.24 & 546 & 0.52 & 129 & 0.28
\end{tabular}

Minimum

Maximum

Difference

$\begin{array}{lccc}\text { Economic variables } & & & \\ \text { County unemployment rate } & 6.48 & 8.69 & 2.20 \\ \text { State unemployment rate } & 4.91 & 7.16 & 2.25 \\ \text { County employment growth } & -0.39 & 3.36 & 3.76 \\ \text { State employment growth } & -0.68 & 3.35 & 4.03 \\ \text { County personal income growth } & 1.10 & 4.65 & 3.55 \\ \text { State personal income growth } & 1.02 & 4.35 & 3.34 \\ \text { County per capita personal income growth } & 0.51 & 4.27 & 3.76 \\ \text { State per capita personal income growth } & 0.58 & 3.45 & 2.86\end{array}$

NOTE: The "large change" test measures the percentage of a large change in the bank performance variable explained by a large change in the economic variable. The ratio is computed as $\chi=\gamma \Delta X / \Delta Y$, where $\gamma$ is the regression coefficient, $\Delta X$ is a large change in the economic variable, and $\Delta Y$ is a large change in the bank performance ratio. A large change in the bank performance ratio is measured by calculating the average difference between a CAMELS 2-rated bank and a CAMELS 3-rated bank in the sample. For example, the average 2- and 3-rated banks had nonperforming loan-to-total loan ratios of 1.53 percent and 2.64 percent, respectively. The difference of 1.11 percent is a "large" change. The benchmark for a "large" change in the economic variable is the maximum change in the average annual values over the sample period. For example, the minimum average county unemployment rate between 1990 and 1997 was 6.48 percent, and the maximum county unemployment rate was 8.69 percent. The difference of 2.2 percentage points is considered a "large" change.

Adjusted ROA, net income plus provision expense as a percentage of total assets; nonperforming loans, loans past due 90 days or more plus nonaccrual loans as a percentage of total loans; loan losses, charge-offs minus recoveries as a percentage of total loans; and $O R E O$, other real estate owned as a percentage of total assets.

cance of the county coefficient, $\gamma_{1}$. A significant coefficient indicated that economic changes at the county level had statistically important effects on small rural bank performance. We placed little emphasis on the overall model fit $\left(R^{2}\right)$ because we were not attempting to fully explain bank performance.

\section{Economic Significance Benchmarks}

Economic significance is more difficult to assess than statistical significance. One cannot simply use the size of the regression coefficients to judge economic significance because of different variances among the regression variables. For example, state unemployment rates are typically less variable than county unemployment rates. An increase of 1 percentage point in the state unemployment rate represents a lower probability event than a 1 percentage point change in a county unemployment rate. To control for the differing variances of economic and bank data, we normalized the regression coefficients by calculating a "beta" coefficient, $\beta=\gamma \sigma_{x} / \sigma_{y}$, where $\gamma$ is the regression coefficient, $\sigma_{x}$ is the standard deviation of the independent variable, and $\sigma_{y}$ is the standard deviation of the dependent variable. The ratio $\beta$-repor ted in the tables as a percentage-measures the effect of a one standard deviation increase in the economic variable on the bank performance variable relative to a one standard deviation change in the bank performance variable. Because previous research demonstrated a link between bank performance measures and state economic data, we used the size of the $\beta$ coefficients for the state economic variables as benchmarks for the economic significance of the county $\beta$ coefficients.

Although a $\beta$ coefficient provides a measure of the relative importance of an independent vari- 


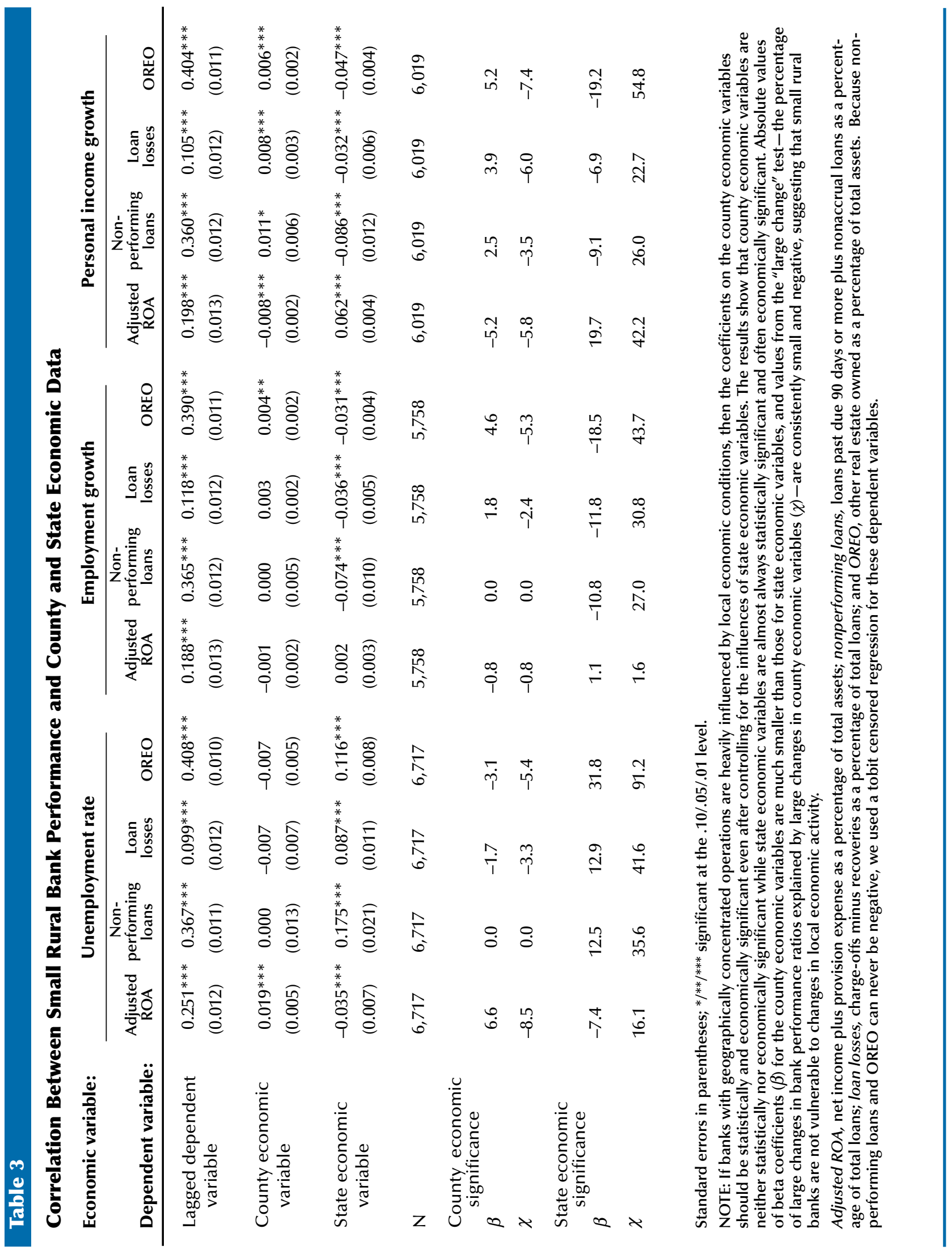


able, it does not provide an adequate measure of the overall importance of a given variable for explaining movements in bank performance ratios. For example, suppose that we regress nonperforming loans on county and state unemployment rates. The regression coefficients are 7 basis points and 17 basis points, respectively, and the $\beta$ coefficients are 4 percent and 10 percent. The state unemployment rate clearly dominates the county unemployment rate using $\beta$ coefficients to judge economic significance, but whether the 7 or 17 basis point coefficient values are economically large remains unclear. The answer depends on the definition of "large" changes in both nonperforming loans and unemployment rates.

We constructed a "large-change" test to determine whether a regression coefficient was economically significant. This test measures the percentage of a large change in the bank performance ratio explained by a large change in the economic variable. Bank examination ratings guided our assessments of large changes in bank performance ratios. Each time a bank is examined, regulators assign a composite rating and an individual rating to each of the CAMELS components. (CAMELS is an acronym that stands for Capital adequacy, Asset quality, Management, Earnings, Liquidity, and Sensitivity [to interest rate risk]). CAMELS ratings range from 1 (the safest banks) to 5 (the riskiest banks). Banks with composite ratings of 1 and 2 are considered to exhibit "strong" and "satisfactory" performances, respectively. Banks that fall below a 2 rating may prompt supervisory action, which could include a board resolution, a memorandum of understanding, a written agreement, or a cease and desist order. Hence, regulators consider a drop from a 2 rating to a 3 rating to be a significant change.

The differences in average bank performance ratios between 2- and 3-rated banks serve as our benchmarks for evaluating economic significance. ${ }^{9}$ We used only bank performance ratios at the time of the bank examination instead of using all performance ratios for 2- and 3-rated banks to avoid endogeneity issues that might arise if supervisors required 3-rated banks to improve performance. Inclusion of all the ratios would potentially decrease the differences between 2- and 3-rated banks. Table 2 displays average measures of performance ratios for banks rated 2 and 3 between 1990 and 1997. For example, the average bank with a 2-rated earnings component had an adjust- ed ROA of 1.61 percent; the average bank with a 3-rated earnings component had an adjusted ROA of 1.12 percent. We consider the 49 basis point spread between the two sets of banks to be economically large.

The last step in measuring economic significance using the large-change test was to identify economically important changes in the economic variables. We identified large changes as the typical changes over the course of a business cycle. The 1990 to 1997 sample period includes the 1990-91 recession and the subsequent recovery and expansion. To identify large changes in the economic data over the business cycle, we calculated the yearly means of each county and state economic variable and computed the differences between the maximum and minimum values. For example, the maximum annual average county unemployment rate was 8.7 percent in 1991, and the minimum value was 6.5 percent in 1997 , a difference of 2.2 percentage points. Large changes in economic variables are also displayed in Table 2.

Somewhat arbitrarily, we interpreted a regression coefficient as economically significant using the large-change test if the maximum change in the economic variable over the business cycle accounted for over one third of the difference in the average bank performance ratio between a 2- and 3-rated bank. The large-change economic significance ratio was calculated as $\chi=\gamma \Delta X I \Delta Y$, where $\gamma$ is the regression coefficient and $\Delta X$ and $\Delta Y$ are economically large changes in the independent and dependent variables, respectively. For example, suppose that a 1 percentage point change in the county unemployment rate increases the nonperforming loan-to-total loan ratio by 7 basis points. If $\Delta X$ is 2.2 percentage points and $\Delta Y$ is 111 basis points, then $\chi=13.9$ percent $(7 \times 2.2 / 111)$ of the change in the bank performance ratio. We would conclude that the county unemployment rate coefficient is economically insignificant. Values of $\chi$ with negative signs imply that the regression coefficients had the theoretically unexpected signs.

\section{RESULTS}

\section{Regression Results}

The regression results indicate that county

\footnotetext{
9 We also computed median differences in bank performance measures, but the differences between mean and median ratios were small.
} 


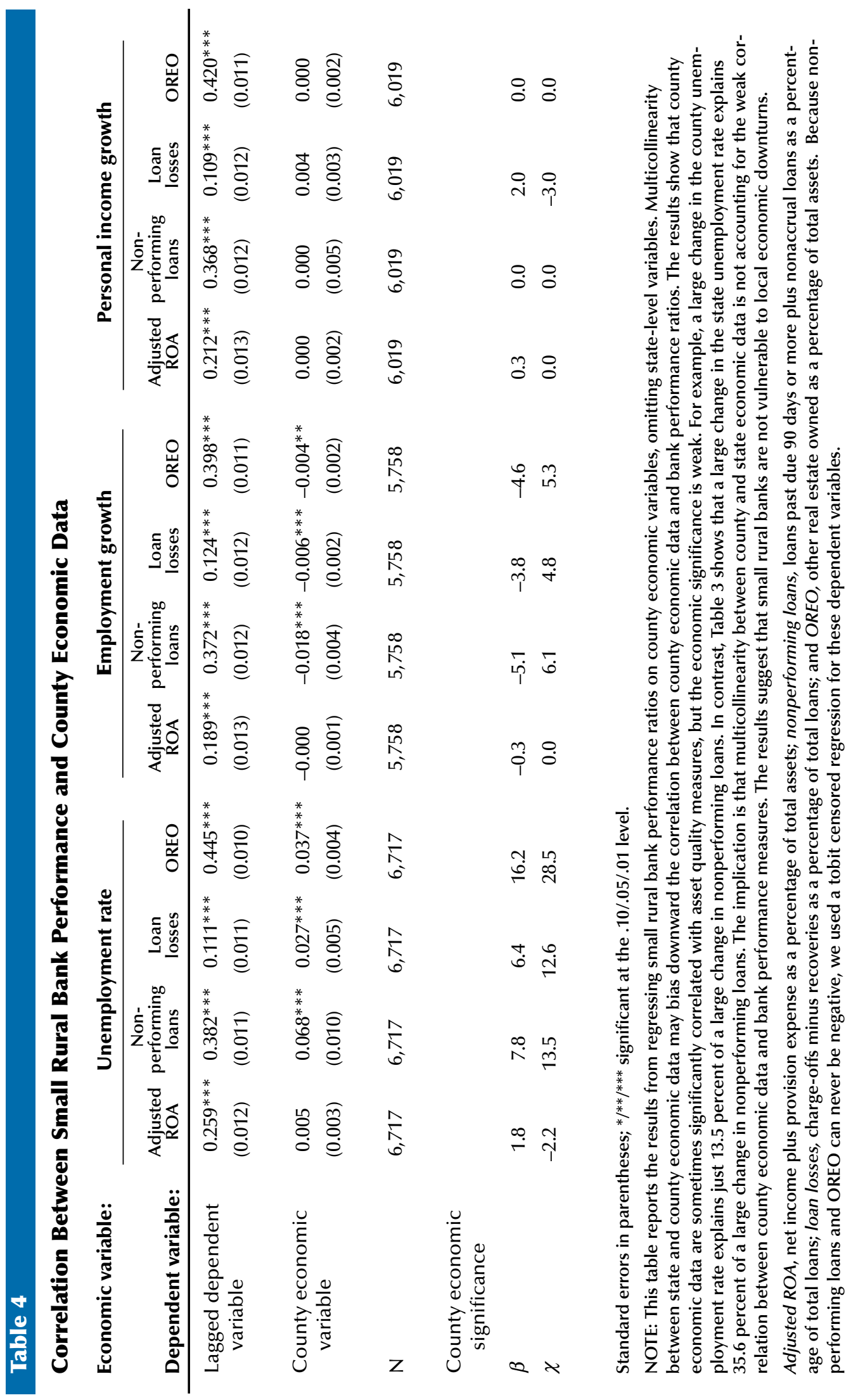


economic data are weakly correlated with bank performance measures. Results are reported in Table 3 along with both measures of economic significance $(\beta$ and $\chi) .{ }^{10}$ None of the county-level coefficients was both statistically significant and had the theoretically expected sign, suggesting that county economic activity did not have an important influence on bank performance. In contrast, state economic data were highly correlated with bank performance measures. In these regressions, 15 out of 16 state-level coefficients were statistically significant at the 1 percent level and had the expected sign. The $\beta$ coefficients for state variables were typically several times higher than the county $\beta$ coefficients. In addition, the largechange measure of economic significance showed that the state unemployment rate accounted for economically significant changes in nonperforming loans, loan losses, and OREO. State personal income growth rates were also economically significant, accounting for 42.2 percent of a large change in adjusted ROA.

Collinearity between each pair of county and state economic data may have reduced the significance of the county-level coefficients. Multicollinearity is likely because county data were derived explicitly from state data, and correlation coefficients between the county and state data were high. Although collinearity among explanatory variables does not bias OLS or tobit estimates, the state economic coefficient might have reduced the statistical importance of the county economic coefficient. To account for this potential effect, we reran equation (1) removing state economic variables from the equation. Results are reported in Table 4.

When state-level data were excluded from the regressions, several county-level economic variables were statistically significant. In particular, we found that changes in county unemployment rates and employment growth affect bank asset quality. Personal income growth, however, had no statistically significant effect on earnings or asset quality.

Although the county unemployment rate was statistically significant when regressed against asset quality ratios, its economic significance was low. The $\beta$ coefficient from a change in the county unemployment rate was just 7.8 percent for nonperforming loans, about half the economic significance of the state unemployment rate coefficient reported in Table 3. Similar results held for loan losses and OREO. The large-change test confirmed the lack of economic significance.
Because the correlation between county economic data and bank performance was not economically significant, the implication is that small rural banks with concentrated operations are not particularly vulnerable to local economic downturns, as currently measured by county-level economic data. The results also suggest that economic data gathered at the county level are not useful to systematically assess community bank performance; however, state economic data may be useful for such a purpose. ${ }^{11}$

\section{Sensitivity of Results to Sample Selection}

The poor correlation between bank performance and county-level economic data could exist because the bank sample included a significant number of banks that were not sensitive to local economic conditions for one reason or another. By removing those banks from the sample, we may be able to uncover a significant relationship. If a significant correlation is found for a smaller subset of banks, then supervisors might wish to focus their attention on this set of banks.

Perhaps some banks had a significant portion of their branches, and hence loan activity, in other counties; therefore, including such banks in the sample weakened the correlation of bank performance with local economic performance. We matched each rural bank in the full sample with the county economic data in which the bank's headquarters resided, even though the bank may have had significant operations in other counties.

To reduce the bias from including banks with significant operations outside of their headquarters county, we re-ran the regressions including only those banks that had 100 percent of their deposits in the headquarters county of the community bank. At the end of each year, the Federal Deposit Insurance Corporation (FDIC) and Office of Thrift Supervision publish the Summary of Deposits, which contains branch deposit informa-

\footnotetext{
10 Because the results for personal income and per capita personal income were similar, we report only the personal income results

11 Besides state data, we experimented with county, contiguous county, nearest MSA, and county data aggregated over only the Eighth District portion of each state. Although coefficients on economic data from the nearest MSA and the Eighth District portions of states are similar to the state-level results, the state economic data are preferred because they are available with a shorter time lag and are subject to less measurement error than the more disaggregated data.
} 


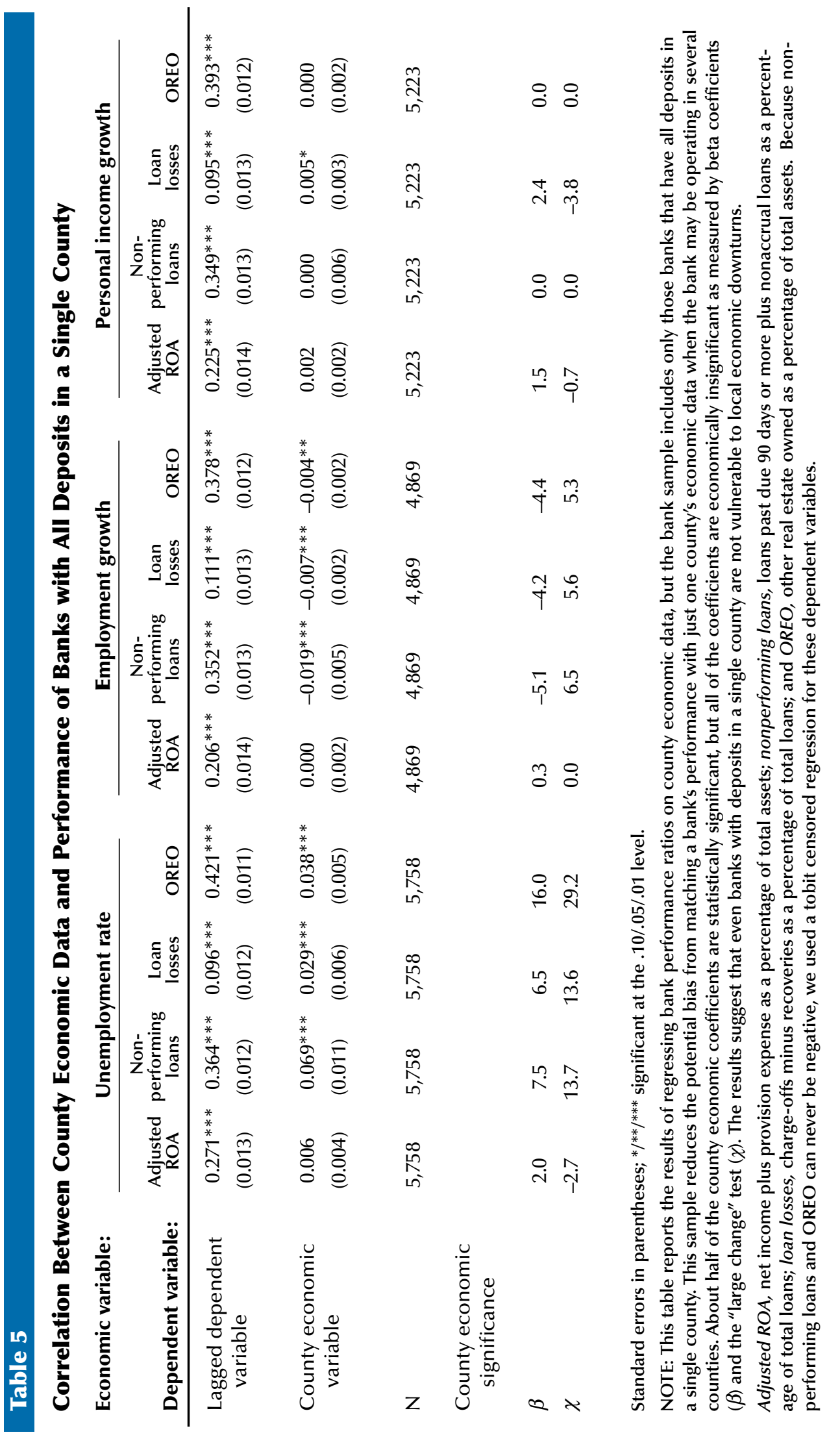


tion for FDIC-insured institutions as of June 30 of that year. Bank deposits inside and outside of a particular county can be computed from the Summary of Deposits data. Of the 6,717 observations in the full sample, 5,758 of them (86 percent) had all deposits in one county. Results are presented in Table 5.

The results from including only banks with all their deposits in the headquarters county were nearly identical to the full sample results. None of the 16 county economic coefficients was economically significant. Banks with all deposits within a single county are no more vulnerable to local economic downturns than banks with deposits in multiple counties.

Another possibility is that many of the community banks in our sample are controlled by larger bank holding companies. Community banks controlled by large BHCs may behave differently from the more isolated banks because they may have a higher share of syndicated loans and other interaction with entities outside their communities. To ensure that none of the banks in the sample was controlled by a large BHC, we included only banks in our sample in which the consolidated assets of the BHC were no more than twice the assets of the bank. For example, a rural bank with $\$ 50$ million in assets owned by a BHC with more than $\$ 100$ million in consolidated assets would have been excluded from the sample. Most banks in the Eighth District were controlled by BHCs smaller than this cutoff because the sample size fell from 6,717 to 4,837 , a decline of only 28 percent. The results are reported in Table 6.

The statistical and economic significance of the sample with large BHCs excluded was similar to the full sample results. The economic significance was small as measured by the $\beta$ coefficients and the large-change tests. The implication is that even the potentially most vulnerable banks-small rural banks not part of relatively large holding companies-are not strongly influenced by changes in available measures of county level economic activity.

An interesting question is why performance at rural banks is not significantly correlated with county economic data. Perhaps such banks were vulnerable to local economic conditions in the past, but changes in intrastate and interstate branching and acquisition laws, advances in transportation and communication technologies, and continued integration of domestic markets have reduced or eliminated this vulnerability. Indeed, Petersen and Rajan (2000) found that community banks have increased their lending to more distant borrowers over time. They found that the distance between small firms and lenders grew from an average of 51 miles in the 1970s to 161 miles in the 1990s. They attributed most of the gain to improvements in gathering and analyzing information. Banks reduced the importance of personto-person contact by increasingly relying on financial statements and credit reports to evaluate potential borrowers. In addition, Gunther and Robinson (1999) found that banks faced less risk from variations in regional economic performance in 1996 than in 1985 due to industry diversification at the state level and geographical diversification by banks. Although it is theoretically possible to test the relationship between bank performance and county economic activity during a time period before branching restrictions were widely relaxed, county-level data limitations reduce the reliability of these estimates.

Regardless of whether banks were systematically vulnerable to local economic conditions in the past, the result that small rural bank performance is only weakly correlated with county economic data suggests that geographic concentration of a bank's offices may not be a significant risk factor for these banks today. The results also suggest that further intrastate branching in Eighth District states will not significantly affect a bank's vulnerability to local economic downturns because this risk factor is already low. ${ }^{12}$

\section{Are Noisy Data to Blame?}

One caveat in drawing implications from the lack of correlation between bank performance measures and county economic data is that the county data may not be of sufficiently high quality (see boxed insert). Perhaps rural banks are affected by county economic conditions but county labor and income data are so noisy that the statistical correlation is masked. Regardless of whether banks are insensitive to local economic downturns

\footnotetext{
${ }^{12}$ Because rural bank performance is significantly correlated with state-level income and labor measures, bank expansion across state lines is more likely to reduce the bank's risk. If interstate loan customers are influenced by a different set of economic events, then diversification benefits will materialize.
} 


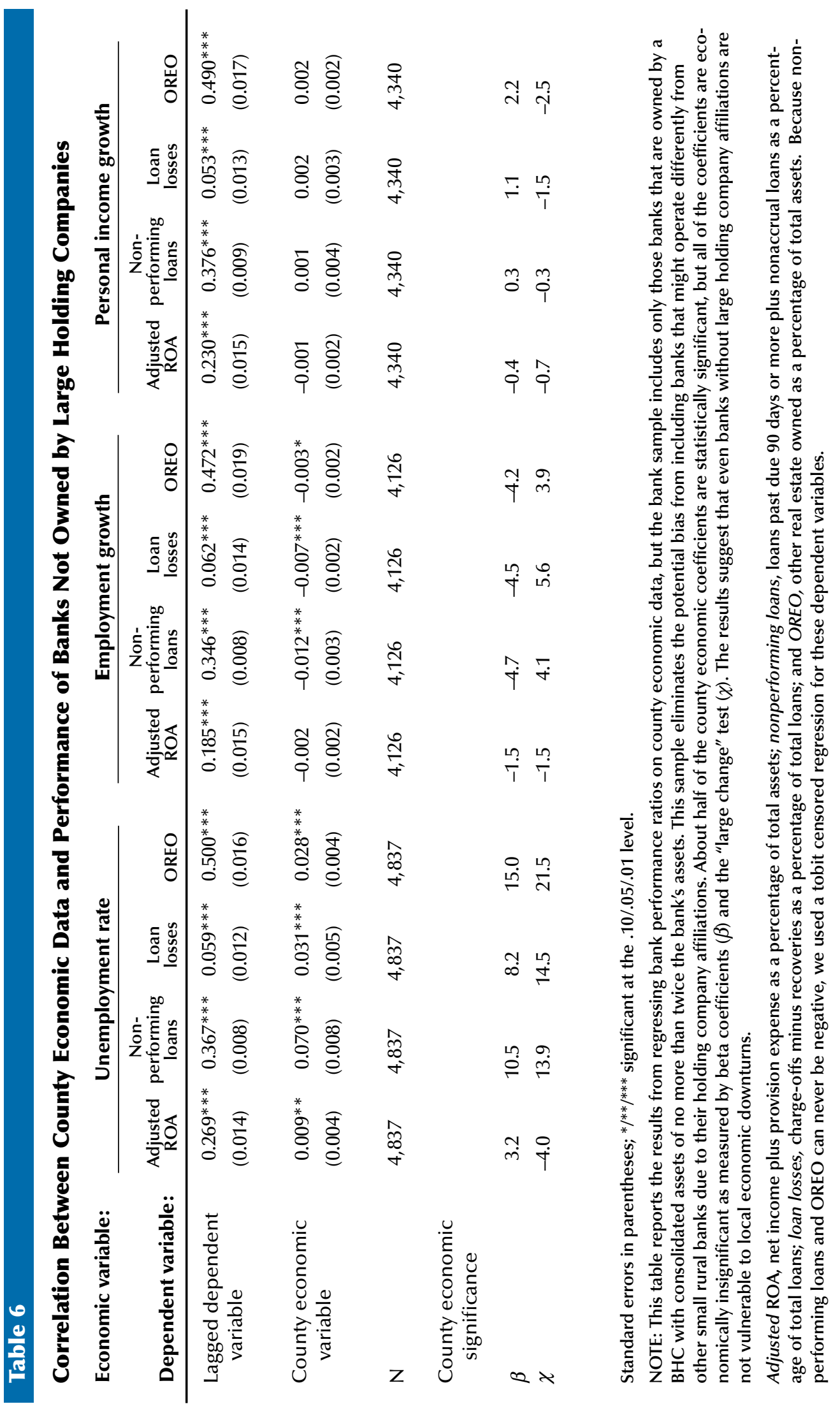




\section{HOW RELIABLE ARE COUNTY-LEVEL ECONOMIC DATA?}

To assess the reliability of county economic data, one must understand how the data are compiled. Because it is too costly to survey enough people directly, the Bureau of Labor Statistics (BLS) computes county unemployment rates by disaggregating state unemployment rates. When constructing local area unemployment statistics, the agency must estimate the number of people unemployed. The BLS constructs unemployment estimates by utilizing data on the number of people currently receiving unemployment insurance benefits in a county. A problem with this procedure, of course, is that insurance benefits may end before the worker finds a new job. To correct for this bias, the BLS uses historical trends to estimate the number of people who have exhausted their benefits. They also estimate the number of unemployed new entrants and reentrants into the labor force who are not eligible or have not filed for unemployment insurance. To be consistent with the more reliable state figures, the county unemployment estimates are adjusted to sum to the state unemployment rate. Clearly, several assumptions must be made to derive county labor estimates, increasing the potential for error.

County-level personal income data are also constructed from state personal income estimates, which in turn are constructed from national estimates. ${ }^{1}$ Personal income of an area is defined as the income received by all the residents of the area. Because most of the source data are reported by the "place of work," the data must be adjusted to a "place of residence" basis. Therefore, the adjustments require making assumptions about cross-county commuting patterns. Data on intercounty commuting are available only every 10 years; interpolation must be used for other years by estimating changes in commuting patterns. Because commuting patterns are likely to change significantly over a 10year period, measurement error is surely introduced and increases over the decade.

Source data used to construct local labor and income estimates are primarily collected for other purposes; therefore, the additional assumptions required to convert these data into countylevel economic data increase the potential for error. However, as long as assumptions remain relatively consistent from year to year, then the change in county labor and income data should be relatively accurate. Therefore, it is not obvious that county economic data are so noisy that they are disguising the true correlation between small rural banks and local economic activity.

${ }^{1}$ Bureau of Economic Analysis (1994).

factor, that bank performance is not significantly correlated with county economic data, and that small rural banks in the Eighth District are not particularly vulnerable to local economic downturns.

Two policy implications arise from these results. First, a priori, little justification exists for imposing more stringent regulatory requirements on banks with geographically concentrated offices than on other banks. For example, all else equal, higher capital standards on geographically concentrated banks are not warranted. Second, coun-

\footnotetext{
${ }^{13}$ Although we cannot discern whether our results are driven by noisy county economic data or that bank performance truly is independent of local economic conditions, ongoing research supports the latter hypothesis. Meyer and Yeager (2000) find that small Eighth District banks with all deposits in a single county bear no more risk than similar banks with deposits across counties. In other words, intrastate diversification fails to reduce bank risk, which is consistent with the hypothesis that small rural banks are not vulnerable to local economic downturns.
} 
ty economic data are not systematically useful in the risk-focused supervision process because the data are weakly correlated with bank performance.

\section{REFERENCES}

Berger, Allen N.; Kashyap, Anil K. and Scalise, Joseph M. "The Transformation of the U.S. Banking Industry: What a Long, Strange Trip It's Been." Brookings Papers on Economic Activity, 1995, (2), pp. 55-218.

; Saunders, Anthony; Scalise, Joseph M. and Udell, Gregory F. "The Effects of Bank Mergers and Acquisitions on Small Business Lending." Journal of Financial Economics, November 1998, 50(2), pp. 187-229.

Board of Governors. "Risk-Focused Framework for the Supervision of Community Banks.” SR 97-25. Division of Banking Supervision and Regulation, 1 October 1997.

Bureau of Economic Analysis. "Local Area Personal Income, 1969-92." U.S. Department of Commerce, September 1994, pp. 1-56.

Federal Deposit Insurance Corporation. "An Examination of the Banking Crises of the 1980s and Early 1990s." History of the Eighties: Lessons for the Future. Vol. 1. 1997.

Gilbert, R. Alton. "Nationwide Branch Banking and the Presence of Large Banks in Rural Areas." Federal Reserve Bank of St. Louis Review, May/June 2000, 82(3), pp. 1328.

Gunther, Jeffery W. and Robinson, Kenneth J. "Industry Mix and Lending Environment Variability: What Does the Average Bank Face?" Federal Reserve Bank of Dallas Economic and Financial Review, Second Quarter 1999, pp. 24-31.

Jayaratne, Jith and Strahan, Philip E. "The Benefits of Branching Deregulation." Federal Reserve Bank of New York Economic Policy Review, December 1997, 3(4), pp. 13-29.

and Wolken, John. "How Important Are Small Banks to Small Business Lending? New Evidence from a Survey of Small Firms." Journal of Banking and Finance, February 1999, 23(2-4), pp. 427-58.
Keeton, William R. "Multi-Office Bank Lending to Small Businesses: Some New Evidence.” Federal Reserve Bank of Kansas City Economic Review, Second Quarter 1995, 80, pp. $45-57$.

Kliesen, Kevin L. and Gilbert, R. Alton. "Are Some Agricultural Banks Too Agricultural?" Federal Reserve Bank of St. Louis Review, January/February 1996, 78(1), pp. 23-35.

Laderman, Elizabeth S.; Schmidt, Ronald H. and Zimmerman, Gary C. "Location, Branching, and Bank Portfolio Diversification: The Case of Agricultural Lending." Federal Reserve Bank of San Francisco Economic Review, Winter 1991, pp. 24-38.

Liang, Nellie and Rhoades, Stephen A. "Geographic Diversification and Risk in Banking." Journal of Economics and Business, November 1988, 40(4), pp. 271-84.

Meyer, Andrew P. and Yeager, Timothy J. "Do Geographically Diversified Banks Operate With Lower Risk?" Supervisory Policy Analysis Working Paper, December 2000.

Neely, Michelle Clark and Wheelock, David C. "Why Does Bank Performance Vary Across States?” Federal Reserve Bank of St. Louis Review, March/April 1997, 79(2), pp. 27 40.

Nickell, Stephen J. "Biases in Dynamic Models with Fixed Effects.” Econometrica, November 1981, 49(6), pp. 1417 26.

Peek, Joe, and Rosengren, Eric S. "The Evolution of Bank Lending to Small Business." Federal Reserve Bank of Boston New England Economic Review, March/April 1998, pp. $27-36$.

Petersen, Mitchell A. and Rajan, Raghuram G. “Does Distance Still Matter? The Information Revolution in Small Business Lending." National Bureau of Economic Research, Working Paper 7685, May 2000.

Spong, Kenneth. Banking Regulation. 5th Ed. Federal Reserve Bank of Kansas City, 2000.

Zimmerman, Gary C. "Factors Influencing Community Bank Performance in California.” Federal Reserve Bank of San Francisco Economic Review, 1996, (1), pp. 26-42. 